\title{
CARDIOVASCULAR AND RENAL ANOMALIES IN TURNER SYNDROME
}

Annelise Barreto Carvalho ${ }^{1}$, Gil Guerra Júnior ${ }^{2}$, Maria Tereza Matias Baptista ${ }^{3}$, Antonia Paula Marques de Faria ${ }^{4}$, Sofia Helena Valente de Lemos Marini ${ }^{5}$, Andréa Trevas Maciel Guerra $6 *$

Study conducted at Faculdade de Ciências Médicas - Universidade Estadual de Campinas - UNICAMP, Campinas, SP

${ }^{*}$ Correspondência:

Depto. de Genética Médica

FCM - UNICAMP

Caixa Postal 6111

Campinas - SP

CEP $13083-970$

\begin{abstract}
SUMMARY
OBJEctive. To evaluate the frequency and type of cardiovascular (CV) and renal/collecting system (R/ CS) abnormalities seen in a sample of patients with Turner Syndrome (TS) and to verify the proportion of those anomalies detected only after diagnosis was established.

METHods. Retrospective study of 130 patients with TS diagnosed in an outpatient setting between 1989 and 2006. The mean age at diagnosis was 11.9 years. Data were obtained by personal history of $\mathrm{CV}$ and R/CS disorders and by results of echocardiogram and ultrasonography of the kidneys and collecting system performed after diagnosis.

Results. $25.6 \%$ of patients who underwent echocardiograms presented CV abnormalities. Among them, mitral regurgitation (21.4\%), bicuspid aortic valve (19\%) and aortic coarctation (19\%) were the most frequent. R/CS anomalies were found in $29.3 \%$ of patients who underwent ultrasonography. Among them, duplication of the collecting system and hydronephrosis (25\% each) and horseshoe kidney (21.2\%) were the most frequent. In about $80 \%$ of cases there was no previous knowledge of these anomalies.

ConcLusion. The frequency of $\mathrm{CV}$ and R/CS abnormalities found in this study was similar to that of previous studies, but most were found in routine exams after TS diagnosis. Thus, early detection of associated anomalies depends on early detection of TS.
\end{abstract}

KEY wORDS: Congenital abnormalities. Heart Defects, Congenital. Kidney diseases. Turner syndrome.

\section{INTRODUCTION}

Turner syndrome (TS) affects about 1:2,500 female newborns ${ }^{1}$ and is due to partial or total loss of the second sex chromosome. There is great variability in cytogenetic findings, including the 45,X karyotype, mosaics without structural abnormalities (as mos 45, X/46, XX and mos 45,X/46,XY) and structural abnormalities with or without mosaicism (as isochromosomes and marker chromosomes).

TS phenotype is highly variable, ranging from "typical" clinical conditions to girls and women almost indistinguishable from the general population. The most evident features to raise clinical suspicion depend on age. During gestation, for instance, clinical suspicion must be raised in female fetuses with hygroma colli, fetal hydrops, heart defects and increased nuchal translucency?2. In the newborn, the finding of low birth length, webbed neck and lymphedema of the dorsum of hands and feet also points to diagnosis of TS.
From the first years of life until the beginning of adolescence, short stature is the most constant feature leading to diagnosis; afterwards, pubertal delay due to gonadal dysgenesis is also found in most cases. These cardinal features - short stature and primary hypogonadism - may be associated with various dysmorphic signs, including triangular face, ptosis, epicanthal folds, strabism, posteriorly rotated ears, high-arched palate, micrognathia, retrognathism, short or webbed neck, hypoplasia of $4^{\text {th }}$ metacarpals, cubitus valgus and multiple pigmented nevi. There may also be congenital defects of heart, kidney and collecting system and also autoimmune and endocrine disorders, among others ${ }^{3}$.

During the last 15 years, most studies have shown a 20-30\% frequency of congenital cardiovascular disorders among patients with TS, particularly bicuspid aortic valve (BAV) and aortic coarctation $(\mathrm{AoC} O)^{4-8}$. There is also a high prevalence of abnormal electrocardiographic findings, including prolongation of the QTc interval ${ }^{9}$. Renal and/or collecting system malformations have been found in $30-40 \%$ of cases; including horseshoe kidney, renal malrotation and collecting system malformations ${ }^{10-12}$.

1. Mestre em Saúde da Criança e do Adolescente - Faculdade de Ciências Médicas - Universidade Estadual de Campinas - FCM - UNICAMP e médica da Secretaria Estadual de Saúde do Ceará

2. Livre-Docente em Pediatria - Professor Associado da Faculdade de Ciências Médicas - Universidade Estadual de Campinas - FCM - UNICAMP, Campinas, SP

3. Doutora em Ciências Médicas e Professora Colaboradora da Faculdade de Ciências Médicas - Universidade Estadual de Campinas - FCM - UNICAMP, Campinas, SP

4. Livre-Docência em Genética Clínica - Professora Associada da Faculdade de Ciências Médicas - Universidade Estadual de Campinas - FCM - UNICAMP, Campinas, SP

5. Doutora em Saúde da Criança e do Adolescente - Professora Assistente Doutora da Faculdade de Ciências Médicas - Faculdade de Ciências Médicas - Universidade Estadual de Campinas - FCM - UNICAMP

6- Livre-Docência em Genética Clínica - Professora Titular da Faculdade de Ciências Médicas - Faculdade de Ciências Médicas - Universidade Estadual de Campinas FCM - UNICAMP, Campinas, SP 
In clinical practice many of these congenital anomalies do not present symptoms, being often detected only after diagnosis of TS is established. As such, early diagnosis and treatment of associated disorders frequently depend on early diagnosis of TS. This work was carried out to study the frequency of cardiovascular and renal/collecting system disorders among patients with TS and to ascertain the proportion of these anomalies detected only after diagnosis of the chromosome abnormality was achieved.

\section{Methods}

Retrospective study based on data collected from the medical files of 157 patients which were referred to our service between 1989 and 2006 due to short stature, primary hypogonadism and/or congenital anomalies compatible with TS. Patients were studied according to the same clinical protocol, and diagnosis of TS was confirmed by karyotypic study performed on peripheral blood lymphocytes in all patients (mean number of metaphases= 49; range: 11 to 100). Twenty seven cases were excluded because reliable follow-up data were not available. Thus, 130 patients were included in the study.

At the time of diagnosis, age ranged from 0.1 to 32.2 years (mean: 11.9 years). Thirteen patients were diagnosed during the first year of life, 41 between 1.1 and 10 years, 68 between 10.1 and 20 years, and eight patients were more than 20 years old. The 45,X karyotype was found in 56 patients (43.1\%), 46 (35.4\%) had mosaicism without structural alterations and 28 (21.5\%) had structural abnormalities of the sex chromosomes (Table 1).

The following data were analyzed: personal history of cardiovascular or renal/collecting system disorders; results of two-dimensional Doppler transthoracic echocardiogram (ECHO) and ultrasonography (US) of the kidneys and collecting system, which were both done after diagnosis of TS in a tertiary care university hospital; and cardiovascular or renal surgeries carried out afterwards. The work was approved by the local Ethics Committee (439/2008).

Table 1 - Karyotypes of the 130 patients with Turner syndrome

\begin{tabular}{|c|c|c|}
\hline Karyotype & $\mathbf{n}$ & $(\%)$ \\
\hline X chromosome monosomy $(45, X)$ & 56 & 43.1 \\
\hline Mosaic without structural abnormality & 46 & 35.4 \\
\hline $\operatorname{mos} 45, X / 46, X X$ & 44 & \\
\hline $\operatorname{mos} 45, X / 46, X Y$ & 2 & \\
\hline $\begin{array}{l}\text { Structural abnormality with or without } \\
\text { mosaicism }\end{array}$ & 28 & 21.5 \\
\hline $\operatorname{mos} 45, X / 46, X, i(X q)$ & 11 & \\
\hline $46, X, i(X q)$ & 10 & \\
\hline $\operatorname{mos} 45, X / 46, X X / 46, X, i(X q)$ & 1 & \\
\hline $\operatorname{mos} 45, X / 46, X,+$ mar & 5 & \\
\hline $\operatorname{mos} 46, X X / 46, X$, del(Xp) & 1 & \\
\hline Total & 130 & 100.0 \\
\hline
\end{tabular}

Descriptive statistical analysis was followed by comparison of the frequency of cardiovascular and renal/collecting system disorders according to karyotype by Pearson's Chi-square and Fisher's exact tests. The SPSS for Windows software, version 11.0 (SPSS, Inc., Chicago, IL, USA) was used for data analysis.

\section{Results}

ECHO was performed in 121 patients; among them, seven (5.8\%) had previous history of cardiovascular anomalies: aortic and mitral insufficiency which were attributed to rheumatic disease; AoCo; and atrial septal defect (ASD), mitral and tricuspid insufficiency (all previously submitted to surgery); BAV; ASD, BAV and AoCo; mild mitral insufficiency; and isolated ASD (one case of each).

Of the 121 patients, 31 (25.6\%) had a total of 42 cardiovascular anomalies, particularly mitral insufficiency (9/42 - 21.4\%), BAV (8/42 - 19\%) and AoCo (8/42 - 19\%) (Table 2). Five of the 31 patients (16\%) were submitted to cardiovascular surgery, three of them before TS diagnosis, as already cited, and two after the diagnosis was made: one of them had AoCo and BAV and the other a severe mitral insufficiency.

Cardiovascular anomalies were not associated to karyotype: they were found in $29.6 \%$ (16/54) of $45, \mathrm{X}$ patients, $17 \%$ $(7 / 41)$ of those who had sex chromosome mosaicism and $30.8 \%(8 / 26)$ of those with structural abnormalities $(p=0.30)$. BAV and/or AoCo were found in 9/16 45,X patients, 3/7 with sex chromosome mosaicism and none of the eight girls with a

Table 2 - Results of echocardiogram of the 121 patients with Turner syndrome

\begin{tabular}{lll}
\hline Result & $\mathrm{n}$ & $\%$ \\
\hline Normal & 90 & 74.4 \\
Abnormal & 31 & 25.6 \\
$\mathrm{MI}$ & 5 & \\
$\mathrm{BAV}$ & 4 & \\
AoCo & 4 & \\
BAV + AoCo & 4 & \\
$\mathrm{Al}$ & 3 & \\
$\mathrm{MI}+\mathrm{Al}$ & 2 & \\
$\mathrm{MVP}$ & 2 & \\
$\mathrm{MVP}+\mathrm{ASD}$ & 1 & \\
ASD & 1 & \\
ASD $+\mathrm{MI}+\mathrm{TI}$ & 1 & \\
$\mathrm{MI}+\mathrm{PI}+\mathrm{TI}$ & 1 & \\
TI & 1 & $\mathbf{1 0 0 . 0}$ \\
PLSVC & 1 & \\
Pericardic effusion & 1 & \\
Total & 121 & \\
\hline
\end{tabular}

$\mathrm{Al}=$ aortic insufficiency; $\mathrm{AoCo}=$ aortic coarctation; $\mathrm{ASD}=$ atrial septal defect; $\mathrm{BAV}=$ bicuspid aortic valve; $\mathrm{MI}=$ mitral insufficiency; $\mathrm{MVP}=$ mitral valve prolapse; $\mathrm{PI}=$ pulmonar insufficiency; $\mathrm{PLSVC}=$ persistent left superior vena cava; $\mathrm{TI}=$ tricuspid insufficiency 
structural abnormality. Frequency of BAV and/or CoAo among patients with and without structural abnormalities was significantly different $(p=0.01)$.

US was performed in 123 patients; among them, seven (5.7\%) had previous history of renal/collecting system anomalies: horseshoe kidney (two cases); left hydronephrosis; multicystic kidneys; hydronephrosis with vesicoureteral junction stenosis (VUJS); and double collecting system, hydronephrosis and VUJS (one case each). There was also a patient with grade 3 vesicoureteral reflux (VUR) who had been submitted to surgery.

Fifty two renal/collecting system anomalies were found in 36 of the 123 patients evaluated by US (29.3\%). The most frequent were double collecting system and hydronephrosis (13/52 or $25 \%$ each), horseshoe kidney ( $11 / 52$ or $21.2 \%)$ and renal lithiasis ( $5 / 52$ or $9.6 \%$ ) (Table 3 ). Three of the 36 patients had corrective surgery, one of them before diagnosis of TS, as already cited, and two after diagnosis was established: in both cases nefrectomy was done, one due to multicystic kidney and the other as a consequence of hydronephrosis.

Renal/collecting system anomalies were not associated to karyotype: they were found in 34\% (18/53) of 45,X patients, $25 \%(11 / 44)$ of those who had sex chromosome mosaicism and

Table 3 - Results of ultrasonography of kidneys and collecting system of the 123 patients with Turner syndrome

\begin{tabular}{|c|c|c|}
\hline RESULTS & $\mathrm{n}$ & $\%$ \\
\hline Normal & 87 & 70.7 \\
\hline Abnormal & 36 & 29.3 \\
\hline Horseshoe kidney & 11 & 8.9 \\
\hline isolated & 7 & \\
\hline associated with double collecting system & 3 & \\
\hline associated with hydronephrosis & 1 & \\
\hline Abnormal collecting system & 17 & 13.8 \\
\hline hydronephrosis & 5 & \\
\hline double collecting system & 5 & \\
\hline hydronephrosis + double collecting system & 2 & \\
\hline $\begin{array}{l}\text { hydronephrosis + double collecting system + UVJ } \\
\text { stenosis }\end{array}$ & 1 & \\
\hline hydronephrosis + double collecting system + VUR & 1 & \\
\hline hydronephrosis + malrotation & 1 & \\
\hline hydronephrosis + malrotation + renal lithiasis & 1 & \\
\hline double collecting system + isolated cyst & 1 & \\
\hline Renal lithiasis & 4 & 3.3 \\
\hline Other (isolated anomalies) & 4 & 3.3 \\
\hline renal calcifications & 1 & \\
\hline renal malrotation & 1 & \\
\hline multicystic kidney & 1 & \\
\hline VUR & 1 & \\
\hline Total & 123 & 100.0 \\
\hline
\end{tabular}

UVJ = ureterovesical junction; VUR = vesicoureteral reflux.
$27 \%(7 / 26)$ of those with structural abnormalities $(p=0.60)$. The frequency of horseshoe kidney among $45, \mathrm{X}$ patients and those with sex chromosome mosaicism and structural abnormalities was $6 / 18,1 / 11$ and $4 / 7(p=0.09)$, while that of double collecting system was $8 / 18,3 / 11$ and $2 / 7$, respectively $(p=0.58)$.

In 13 of the 130 patients (10\%) there were both cardiovascular and renal/collecting system anomalies.

\section{Discussion}

Cardiovascular anomalies are the main cause of intrauterine death in $\mathrm{TS}^{13}$, and about $10 \%$ of newborns with this syndrome present severe and frequently lethal abnormalities, mainly left heart hypoplasia ${ }^{14}$. Thus, studies concerning frequency of these anomalies in TS actually refer to girls and women who have escaped intrauterine and neonatal selection, with isolated defects which are usually detected only after diagnosis of the chromosome abnormality ${ }^{15}$.

The frequency of cardiovascular anomalies observed in this work $(25.6 \%)$ was similar to other studies; interestingly, mitral insufficiency was the most frequent alteration, instead of BAV or AoCo. Most studies showed a predominance of BAV among girls with TS $(10-18.5 \%)^{15}$, a much higher frequency then that of the general population $(1-3 \%)^{16}$. When ECHO is associated with magnetic resonance imaging, BAV may be found in up to $29 \%$ of TS patients ${ }^{15}$. The frequency of BAV in our sample $(6.7 \%)$, though lower than that found in most studies was similar to that in a recent work (6\%), in which mitral insufficiency was the most frequent finding (18\%). Also there were no cases of BAV and AoCo among patients with structural chromosome abnormalities (mosaic and non-mosaic) ${ }^{16}$.

There are significant variations among studies on the type and frequencies of cardiovascular anomalies associated with TS $4,5,7$. In addition, patients diagnosed incidentally have fewer cardiac defects than those diagnosed on clinical grounds, thus supporting the theory that significant bias exists in our current understanding of the phenotype and medical problems associated with TS ${ }^{17}$.

As stressed by Fergusson-Smith ${ }^{18}$, an unselected series of TS cases could only be obtained by chromosome analysis of large samples of the general population. As most samples have been selected for study on the basis of clinical criteria, ascertainment of bias must also be borne in mind in the interpretation of karyotypephenotype correlations. Nevertheless, a significant association of BAV and/or CoAo with 45,X monosomy and mosaicism without structural abnormalities was found in our sample. Furthermore, the higher frequency of horseshoe kidney among patients with 45,X monosomy and structural abnormalities almost reached significance, thus indicating that among different karyotypes, patients with $45, \mathrm{X}$ may have the highest incidence of cardiovascular abnormalities.

Screening of BAV in asymptomatic TS patients is very important, due to a significant risk of endocarditis, aortic valve disfunction (stenosis or insufficiency) and aortic aneurism, which may lead to dissection or rupture ${ }^{15,20}$. AoCo, which was found in this sample with a frequency of $6.6 \%$, similar to other studies $(4-14 \%)^{21}$, may result in dissection and rupture of the aorta. Factors associated with ascending aortic dissection include BAV, dilation of ascending aorta and hypertension ${ }^{22}$. TS patients who exhibit webbed neck had a frequency of BAV and AoCo four-fold 
higher than that of those without this feature ${ }^{23}$, which led to the hypothesis of a pathogenic association beween AoCo and increased lymphatic pressure associated with jugular lymphatic sac obstruction ${ }^{24-25}$.

Due to the high incidence of cardiovascular anomalies in TS and resulting risk of acute and chronic complications, all newly diagnosed individuals need a baseline cardiovascular evaluation including two-dimensional and color Doppler ECHO and a baseline electrocardiogram. Blood pressure should also be monitored frequently on a regular basis. Though ECHO is usually effective in infants and children, if all aortic valve leaflets are not clearly visualized to exclude significant abnormalities, cardiac magnetic resonance imaging should be performed ${ }^{26-28}$. Patients with significant cardiovascular defects need continued monitoring by a cardiologist ${ }^{26}$.

Both type and frequency (29.3\%) of kidney/collecting system abnormalities observed in this sample were similar to data obtained from pertinent literature ${ }^{11}$. Although most structural anomalies may be initially asymptomatic, there may be a higher risk of hypertension, urinary tract infection and hydronephrosis ${ }^{11,27}$, which emphasizes need for early diagnosis. As a consequence, all girls with TS must have a renal US performed at diagnosis, allowing diagnosis of clinically significant abnormalities, particularly collecting system malformations and also horseshoe kidneys and malrotation or other positional abnormalities ${ }^{26}$.

In Brazil mean age at diagnosis (about 12 years) ${ }^{29}$ indicates that in many cases clinical suspicion only arises when the second most frequent clinical feature - primary hypogonadism is also found. Though the phenotype of TS is highly variable, a cytogenetic evaluation of girls with short stature and low growth velocity of unknown etiology, with or without a "typical" clinical condition ${ }^{26}$ would allow early diagnosis of a significant number of patients and also early diagnosis and monitoring of associated congenital anomalies.

In conclusion, most patients in this study had no previous knowledge of cardiovascular and kidney/collecting system abnormalities, although serious congenital defects were found in some of these patients after diagnosis of TS. Thus, early diagnosis of these associated anomalies depends mostly upon early diagnosis of TS.

\section{ACKNOWLEDGMENTS}

The authors are grateful to the Cytogenetics Laboratory of the Department of Medical Genetics of the University of Campinas (UNICAMP) and to the Radiology Service of the University Hospital.

This work was supported by FUNCAP (Fundação Cearense de Apoio ao Desenvolvimento Científico e Tecnológico).

\section{Conflict of interest: none}

\section{Resumo}

Anomalias Cardiovasculares e Renais Na SíndRome de TuRner

Objetivo. Analisar a frequência e os tipos de anomalias cardiovasculares (CV) e de anomalias renais ou de sistema coletor (R/SC) em uma amostra de pacientes com síndrome de Turner (ST) e verificar a proporção dessas anomalias que só foram detectadas após o estabelecimento do diagnóstico.
Métodos. Estudo retrospectivo de 130 pacientes com ST diagnosticadas em serviço ambulatorial entre 1989 e 2006. A média de idade ao diagnóstico foi 11,9 anos. Foram coletados dados sobre antecedentes pessoais de anomalias CV e R/SC e resultados de ecocardiograma e ultrassonografia de rins e vias urinárias realizados após o diagnóstico.

Resultados. 25,6\% das pacientes submetidas ao ecocardiograma apresentavam anomalias CV. Dentre elas, as mais frequentes foram a insuficiência mitral (21,4\%), a valva aórtica bicúspide (19\%) e a coarctação da aorta (19\%). Anomalias R/ SC foram observadas em 29,3\% das pacientes submetidas à ultrassonografia. Dentre elas, a duplicação do sistema coletor (25\%), a hidronefrose (25\%) e o rim em ferradura (21,2\%) foram as alterações mais frequentes. Em cerca de $80 \%$ dos casos não havia conhecimento prévio dessas anomalias.

Conclusão. A frequência de anomalias CV e anomalias R/ SC verificada em nosso estudo foi semelhante à de outros trabalhos, mas a maioria só foi detectada em exames rotineiros após o diagnóstico de ST. A detecção precoce das anomalias associadas depende, portanto, do diagnóstico precoce dessa sindrome. [Rev Assoc Med Bras 2010; 56(6): 655-9]

UnITERMos: Anormalidades congênitas. Cardiopatias congênitas. Nefropatias. Síndrome de Turner.

\section{RefERENCES}

1. Nielsen J, Wohlert M. Chromosome abnormalities found among 34,910 newborn children: results from a 13-year incidence study in Arhus, Denmark. Hum Genet. 1991;87:81-3.

2. Papp C, Beke A, Mezei G, Szigeti Z, Bán Z, Papp Z. Prenatal diagnosis of Turner syndrome: report on 69 cases. J Ultrasound Med. 2006;25:711-7.

3. Gravholt $\mathrm{CH}$. Clinical practice in Turner syndrome. Nat Clin Pract Endocrinol Metab. 2005;1:41-52.

4. Hou JW, Hwu WL, Tsai WY, Lee JS, Wang TR, Lue HC. Cardiovascular disorders in Turners syndrome and its correlation to karyotype. J Formos Med Assoc. 1993;92:188-9.

5. Gøtzsche CO, Krag-Olsen B, Nielsen J, Sørensen KE, Kristensen BO. Prevalence of cardiovascular malformations and association with karyotypes in Turners syndrome. Arch Dis Child. 1994;71:433-6.

6. Mazzanti L, Cacciari E. Congenital heart disease in patients with Turners syndrome. Italian Study Group for Turner Syndrome (ISGTS). J Pediatr. 1998; 133:688-92.

7. Prandstraller D, Mazzanti L, Picchio FM, Magnani C, Bergamaschi R, Perri A, et al. Turners syndrome: cardiologic profile according to the different chromosomal patterns and long-term clinical follow-up of 136 nonpreselected patients. Pediatr Cardiol. 1999;20:108-12.

8. VölkI TM, Degenhardt K, Koch A, Simm D, Dörr HG, Singer H. Cardiovascular anomalies in children and young adults with Ullrich-Turner syndrome: the Erlangen experience. Clin Cardiol. 2005;28:88-92.

9. Bondy CA, Van PL, Bakalov VK, Sachdev V, Malone CA, Ho VB, et al. Prolongation of the cardiac QTC interval in Turner syndrome. Medicine (Baltimore). 2006;85:75-81.

10. Lippe B, Geffner ME, Dietrich RG, Boechat MI, Kangarloo H. Renal malformations in patients with Turner syndrome: imaging in 141 patients. Pediatrics. 1988;82:852-6.

11. Bilge I, Kayserili H, Emre S, Nayir A, Sirin A, Tukel T, et al. Frequency of renal malformations in Turner syndrome: analysis of 82 Turkish children. Pediatr Nephrol. 2000;14:1111-4.

12. Chang P, Tsau YK, Tsai WY, Tsai WS, Hou JW, Hsiao PH, et al. Renal malformations in children with Turner's syndrome. J Formos Med Assoc. 2000;99:796-8.

13. Surerus E, Huggon IC, Allan LD. Turner's syndrome in fetal life. Ultrasound Obstet Gynecol. 2003;22:264-7.

14. SybertVP. Cardiovascularmalformations and complications in Turnersyndrome. Pediatrics. 1998;101:E11.

15. Sachdev V, Matura LA, Sidenko S, Ho VB, Arai AE, Rosing DR, et al. Aortic valve disease in Turner syndrome. J Am Coll Cardiol. 2008;51:1904-9.

16. Poprawski K, Michalski M, Ławniczak M, Łacka K. Cardiovascular abnormalities in patients with Turner syndrome according to karyotype: own experience and literature review. Pol Arch Med Wewn. 2009;119:453-60. 
17. Gunther DF, Eugster E, Zagar AJ, Bryant CG, Davenport ML, Quigley CA. Ascertainment bias in Turner syndrome: new insights from girls who were diagnosed incidentally in prenatal life. Pediatrics. 2004;114:640-4.

18. Fergusson-Smith MA. Karyotype-phenotype correlations in gonadal dysgenesis and their bearing on the pathogenesis of malformations. J Med Genet. $1965 ; 2: 142-55$

19. Braverman AC, Güven H, Beardslee MA, Makan M, Kates AM, Moon MR. The bicuspid aortic valve. Curr Probl Cardiol, 2005;30:470-522.

20. Gravholt CH, Landin-Wilhelmsen K, Stochholm K, Hjerrild BE, LedetT, Djurhuus $\mathrm{CB}$, et al. Clinical and epidemiological description of aortic dissection in Turners syndrome. Cardiol Young. 2006;16:430-6.

21. Gravholt $\mathrm{CH}$. Turner syndrome and the heart: cardiovascular complications and treatment strategies. Am J Cardiovasc Drugs. 2002;2:401-13.

22. Badmanaban B, Mole D, Sarsam MA. Descending aortic dissection post coarctation repair in a patient with Turners syndrome. J Cardiol Surg. 2003;18:153-4.

23. Loscalzo ML, Van PL, Ho VB, Bakalov VK, Rosing DR, Malone CA, et al. Association between fetal lymphedema and congenital cardiovascular defects in Turner syndrome. Pediatrics. 2005;115:732-5.

24. Van Der Putte SCJ. Lymphatic malformation in human fetuses: a study of fetuses with Turner's syndrome or status Bonnevie-Ullrich. Virch Arch Hum Pathol Anat Histol. 1977;376:233-46.
25. Clark EB. Neck web and congenital heart defects: a pathogenic association in 45,X0 Turner syndrome? Teratology. 1984;29:355-61.

26. Bondy CA and Turner Syndrome Study Group. Care of girls and women with Turner syndrome: A guideline of the Turner Syndrome Study Group. J Clin Endocrinol Metab. 2007;92:10-25.

27. Saenger $\mathrm{P}$, Wikland KA, Conway GS, Davenport M, Gravholt $\mathrm{CH}$, Hintz R, et al. Recommendations for the diagnosis and management of Turner syndrome. J Clin Endocrinol Metab. 2001;86:3061-9.

28. Frias JL, Davenport ML, Committee on Genetics, and Section on Endocrinology. Health supervision for children with Turner syndrome. Pediatrics. 2003;111: 692-702.

29. Carvalho AB, Guerra-Junior G, Baptista MT, Marques-de-Faria AP, LemosMarini SH, Maciel-Guerra AT. Turner syndrome: a pediatric diagnosis frequently made by non-pediatricians. J Pediatr (Rio J). 2010;86:121-5.

Artigo recebido: 02/01/10

Aceito para publicação: 14/09/10 